\title{
Evaluation of Hygienic Treatment of Biowastes by Anaerobic Digestion in Biogas Plants
}

\author{
Ram Chandra Poudel ${ }^{1}$, Dev Raj Joshi ${ }^{2}$, Nawa Raj Dhakal ${ }^{3}$ and Amrit Bahadur Karki ${ }^{4}$ \\ ${ }^{1}$ National College, Kathmandu \\ ${ }^{2}$ Central Department of Microbiology, Tribhuvan University, Kathmandu \\ ${ }^{3}$ Alternative Energy Promotion Centre, Khumaltar, Lalitpur \\ ${ }^{4}$ Biogas Sector Partnerships (BSP)-Nepal \\ e-mail:joshi_devraj@hotmail.com
}

\begin{abstract}
Anaerobic digestion in biogas plants is one of the biological methods for safe handling of biowastes. We evaluated the fate of coliforms and pathogens in different biowaste and bioslurry samples. Bacteria were enumerated and identified by culture based microbiological methods and parasites were detected microscopically by formal-ether sedimentation technique. The mean loads of total and faecal coliforms were significantly decreased $(\mathrm{P}<0.05)$ with the anaerobic digestion in the biogas plant. Out of 18 bioslurry samples, only 8 (45\%) samples met the USEPA class ' $A$ ' biosolid standard. The mean reduction in load of total and faecal coliforms was observed higher in batch digestion $(\mathrm{P}<$ $0.05)$. The mean load of total and faecal coliforms was significantly $(\mathrm{P}<0.05)$ higher in human and animal excreta. The load of total and faecal coliforms was independent $(\mathrm{P}>0.05)$ of the size of the biogas plant. The result of this study revealed that the degree of sanitizing biowaste depends on digestion type and nature of biowaste.
\end{abstract}

Key words: anaerobic digestion, biogas plant, bioslurry, biowaste, coliforms, pathogens,

\section{Introduction}

Biowaste is any waste capable of undergoing anaerobic or aerobic decomposition (EC 2001a). The type and load of pathogens and indicators in biowaste vary depending upon its type and composition (Lepeuple et al. 2004, Cole et al. 1999). Anaerobic digestion in biogas plants is an effective way of stabilizing and sanitising biowaste (Parawira 2004, Sahlström 2003), the degree of which depends on temperature, time, $\mathrm{pH}$, volatile fatty acids, batch or continuous digestion, bacterial species and their initial load and available nutrients (Smith et al. 2005, Larsen 1994, Strauch 1991). Due to economic and practical reasons most of the biogas plants are run continuously, however, the batchwise method is preferred (Sahlström 2003).

The anaerobically digested residue (bioslurry) is being used for raising soil fertility, improving soil and increasing agricultural production (Stout 1984). Therefore, it must be proven hygienically safe for both people and animals in order to be recycled or reused. Otherwise new possible routes of disease transmission between urban and rural areas are created (Albihn 2001). In Nepal, the biogas plants are largely dominated by the household level biogas plants in rural areas that use animal and human excreta as feeding materials (Karki et al. 2005). However, institutional biogas plants using kitchen waste, fruit and vegetable waste, poultry waste, human excreta, etc as feeding materials are being constructed in the urban areas.

There has been considerable awareness of household and institutional biogas plant needs, but the problems of handling and safe utilization of digested residue (bioslurry) which may contain pathogens have received less attention. Safe utilization of this bioslurry is of paramount importance for health of humans, animals and plants, and also for the social and environmental effects. In this study, we have 
described the fate of indicator (coliforms) and pathogenic microorganisms in different biowastes during anaerobic digestion in the biogas plants.

\section{Materials and Methods}

The study was conducted from October 2008 to January 2009. Biowastes (fruit and vegetable waste, poultry manure, animal dung, kitchen waste etc) that were ready to be used as feeding materials in biogas plant and digested residues (bioslurries) of biogas plant were taken as samples. Altogether 35 samples (17 biowaste and 18 bioslurry samples) were collected from different biogas plants (institutional, household and experimental) within Kathmandu valley. Samples were collected at three different points (lower, upper and median point) in the biowaste and bioslurry pile, mixed and one aliquot of $10 \mathrm{~g}$ or $10 \mathrm{ml}$ was used as a sample. Each sample was divided into two parts for bacterial analysis and parasite detection.

The laboratory setting was maintained at the Microbiology Laboratory of National College, Kathmandu. Biowaste and bioslurry samples were diluted for isolation of enteric and other bacteria. Different microbiological media were used for the detection of different bacteria. Plate count agar for total heterotrophic bacteria, M-Endo agar for total and faecal coliforms, Cetrimide agar for Pseudomonas aeruginosa, Selenite F- broth and Xylose- lysine deoxycholate (XLD) agar for Salmonella spp. and Shigella spp., Alkaline peptone water and Thiosulphate citrate bile sucrose (TCBS) agar for Vibrio spp., Mannitol salt agar for Staphylococcus aureus and Azide Dextrose broth and Azide Dextrose agar for faecal Streptococci. All the bacteria were identified by their morphological and biochemical characteristics. Further, pyocyanin production test (Onbasli \& Aslim 2008, Cheluvappa et al. 2008) was done for Pseudomonas aeruginosa and coagulase test (Cheesbrough 2000) for Staphylococcus aureus. The total and faecal coliforms were enumerated by standard plate count method (APHA 1998). Ten milliliters of homogenized biowaste and bioslurry samples were serially diluted in $90 \mathrm{ml}$ distilled water and $0.1 \mathrm{ml}$ of three different dilutions was spread on respective petri plates. The numbers reported are means of three plates (Benatti et al. 2002, cote et al. 2006). The parasites were detected in biowaste and bioslurry samples by formal-ether sedimentation technique as described by Ridley and Hawgood (1995).

Statistical analysis of the data was performed by SPSS (version 11.5). The t-test and one way ANOVA were calculated to observe any significant relationships among the variables and $\mathrm{P}$ value $<0.05$ was considered statistically significant in both tests. Bacterial load was taken as dependent variables whereas anaerobic digestion, digestion type and biowaste type were the independent variables.

\section{Results}

Altogether 71 isolates of bacteria were obtained from different biowaste samples which belonged to 12 genera: Escherichia coli, Klebsiella spp., Enterobacter spp., Citrobacter frundii, Pseudomonas spp., Proteus spp., Salmonella spp., Shigella spp., Alcaligenes spp., Bacillus spp., Staphylococcus spp. and Enterococcus spp. Similarly, a total of 18 bacterial isolates of 3 genera: Escherichia coli and Citrobacter frundii and Enterococcus spp. were obtained from bioslurry samples. Six different species of parasites were detected from 17 biowaste samples. Entamoeba histolytica, Giardia lamblia, Ascaris lumbricoides, Hymenolepis nana, Enterobius vermacularis and Strongyloides stercoralis were detected in $58.82 \%, 41.17 \%, 23.52 \%$, $11.76 \%, 5.88 \%$ and $5.88 \%$ samples respectively. Out of 18 bioslurry samples, Ascaris lumbricoides and Trichuris trichiura were detected in $11.11 \%$ and $5.55 \%$ samples respectively.

The mean load of total coliforms and faecal coliforms were lower in bioslurry samples than in biowaste samples. A statistically significant correlation was found between anaerobic digestion of biogas plant and the decrease in load of total coliforms $(\mathrm{P}<0.001)$ and faecal coliforms $(\mathrm{P}=0.002)$ (Table 1$)$.

Table 1. Coliforms load with anaerobic digestion

\begin{tabular}{l|l|l|l|l|l}
\hline Coliforms and $\mathrm{pH}$ & Sample (Digestion) & No. of samples & Mean & Standard deviation & P value (t test) \\
\hline \multirow{2}{*}{ Total Coliforms } & Biowaste & 17 & 5.93 & 1.802 & $<0.001$ \\
\cline { 2 - 6 } & Bioslurry & 18 & 3.54 & 1.112 & \\
\hline \multirow{2}{*}{ Faecal Coliforms } & Biowaste & 17 & 4.59 & 1.561 & 0.002 \\
\cline { 2 - 6 } & Bioslurry & 18 & 2.88 & 1.448 & \\
\hline
\end{tabular}


When comparing the microbial quality of bioslurries with the USEPA standard for biosolids, the faecal coliforms load of $8(45 \%)$ samples was found within the USEPA class A biosolids standard $\left(<3 \log _{10}\right)$ while the faecal coliforms load of $10(55 \%)$ samples were found within USEPA class B biosolids standard $\left(<6.3 \log _{10}\right)$ (Fig. 1).

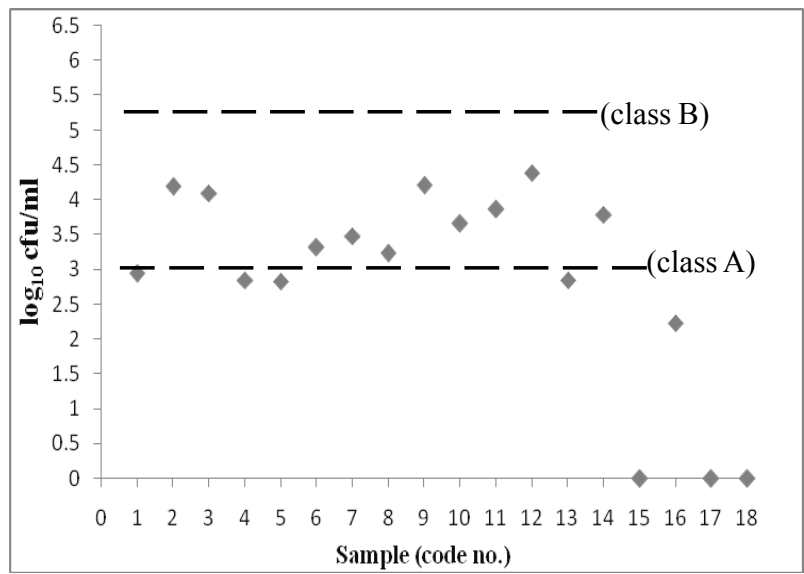

Fig. 1. Comparison of load of faecal coliforms in bioslurries with USEPA standard

The higher mean reduction for both total and faecal coliforms was observed in batch digestion. A statistical significant correlation was found between the digestion type and mean reduction load of total coliform $(\mathrm{P}=0.04)$ and faecal coliform $(\mathrm{P}=0.003)$ (Fig. 2).

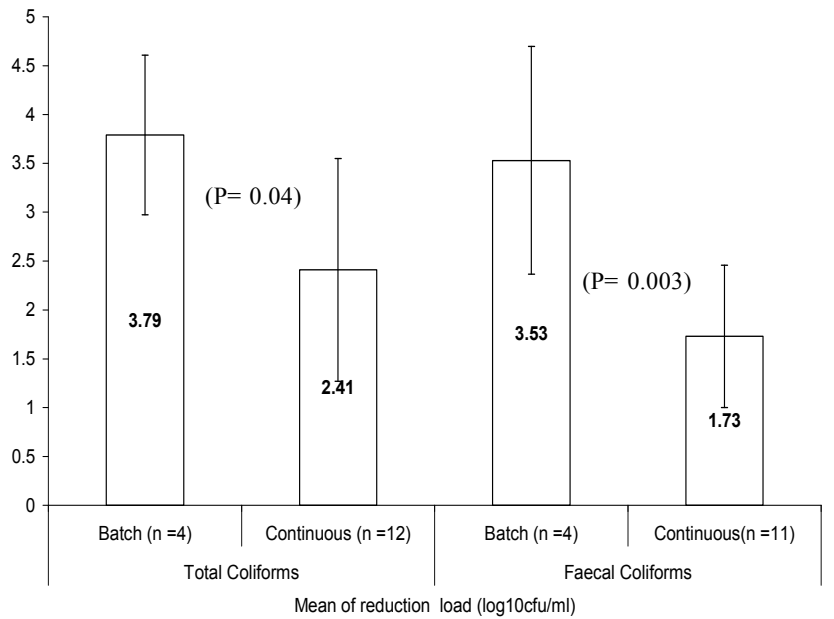

Fig. 2. Reduction of load of coliforms with type of digestion
The mean load of total and faecal coliforms was found to be higher in human and animal waste (HAW) dominated samples. A statistically significant correlation was found between the biowaste type and the load of total coliforms $(\mathrm{P}=0.004)$ and faecal coliforms $(\mathrm{P}<0.001)$ (Fig. 3).

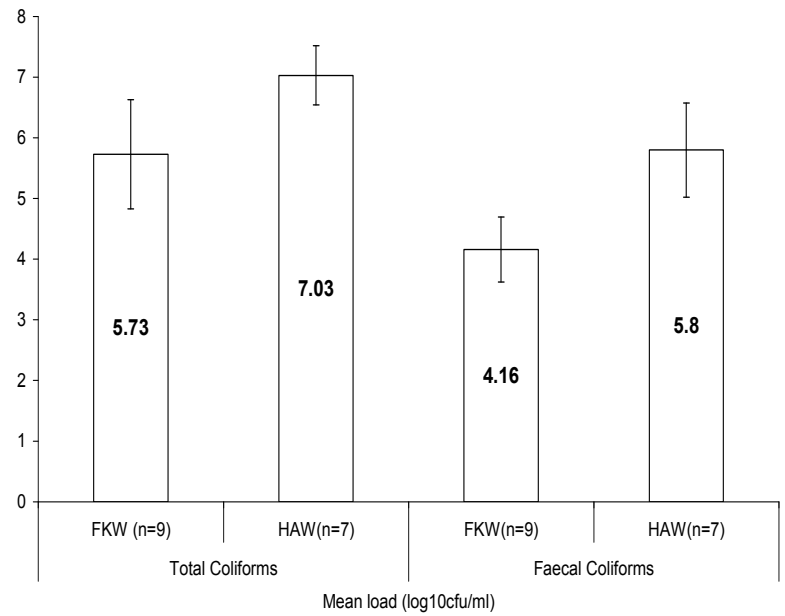

Fig. 3. Coliforms load according to biowaste type

Note: FKW- Fruit, Vegetable and Kitchen Waste, HAWHuman and Animal Waste

The size of the biogas plant was found to be statistically insignificant with the total coliforms $(\mathrm{P}=0.183)($ Table 2$)$ and faecal coliforms $(\mathrm{P}=0.16)$ (Table 3$)$.

Table 2. Reduction load of total coliforms with biogas plants size

\begin{tabular}{l|l|l|l|l}
\hline $\begin{array}{l}\text { Reduction } \\
\text { load } \\
\text { category } \\
\left(\log _{10}\right)\end{array}$ & $\begin{array}{l}\text { No. of } \\
\text { biogas } \\
\text { plants }\end{array}$ & $\begin{array}{l}\text { Mean of } \\
\text { plant size } \\
\left(\mathrm{m}^{3}\right)\end{array}$ & $\begin{array}{l}\text { Standard } \\
\text { deviation }\end{array}$ & $\begin{array}{l}\text { P value } \\
\text { (one way } \\
\text { ANOVA) }\end{array}$ \\
\hline $0-2$ & 3 & 31.00 & 21.283 & 0.183 \\
$2-4$ & 12 & 12.37 & 15.360 & \\
$4-6$ & 1 & 1 & 0 & \\
Total & 16 & 15.16 & 17.411 & \\
\hline
\end{tabular}

Table 3. Faecal coliform reduction load with biogas plants size

\begin{tabular}{l|l|l|c|c}
\hline $\begin{array}{l}\text { Reduction } \\
\text { load } \\
\text { category } \\
\left(\log _{10}\right)\end{array}$ & $\begin{array}{l}\text { No. of } \\
\text { biogas } \\
\text { plants }\end{array}$ & $\begin{array}{l}\text { Mean of } \\
\text { plant size } \\
\left(\mathrm{m}^{3}\right)\end{array}$ & $\begin{array}{l}\text { Standard } \\
\text { deviation }\end{array}$ & $\begin{array}{l}\text { P value } \\
\text { (one way } \\
\text { ANOVA) }\end{array}$ \\
\hline $0-2$ & 6 & 21.83 & 17.279 & 0.16 \\
$2-4$ & 8 & 7.65 & 11.356 & \\
$4-6$ & 1 & 0.35 & 0 & \\
Total & 15 & 12.83 & 15.242 & \\
\hline
\end{tabular}




\section{Discussion}

Biowastes contain different types of pathogenic microorganisms, the type and load of which depends on the type of waste studied (Jenkins et al. 2007). Altogether 71 bacteria under 12 genera and 18 bacteria under 3 genera were isolated from different biowaste and bioslurry samples respectively. Strauch (1991) and Sahlström et al. (2008) reported similar genera of bacteria from the biowaste samples of the biogas plants. Most of the pathogens such as Salmonella spp., Shigella spp. were isolated from faecally contaminated wastes whereas other bacteria such as Staphylococcus spp. and Bacillus spp. were mostly isolated from kitchen and fruit and vegetable wastes. Faecal coliforms were isolated from all (17) biowaste samples and among parasites, Entamoeba histolytica was the most detected parasite which was detected in $10(58.82 \%)$ samples followed by Giardia lamblia, detected in 7 (41.17\%) samples. These two parasites are common and are frequently found in excreta of unhealthy human. The detection of such diverse groups of organisms might be due to different source, composition and type of the biowaste samples. Almost all the biowastes taken were contaminated with at least one type of organism except one i.e. poultry waste which was found to be free from pathogenic and indicator organisms. This might be due to high $\mathrm{pH}$ value (8.85) because of high ammonia content in the poultry waste.

The average microbial load and their types were lower in the bioslurries than in the biowastes. Out of 18 bioslurry samples, coliforms were detected in $55.55 \%$ samples and Enterococcus spp. in $844.44 \%$ samples, and Ascaris spp. and Trichuris trichiura were detected in $11.11 \%$ and $5.55 \%$ samples respectively. No one of the bioslurry samples contained pathogenic bacteria like Salmonella spp., Shigella spp. and Vibrio spp., etc. However, a study performed by YSD (2005) found that out of 132 bioslurry samples, pathogens (other than E. coli) were detected in 63 (48\%) samples. Amongst the detected pathogens, Ascaris spp. was the most predominant (31\%), followed by Taenia spp. (23\%) and Trichuris spp. (14\%) and the other detected pathogens were Giardia spp., hookworm, Trichomonas spp., Diphyllobothrium spp. and Shigella spp. The lower number and type of pathogens detected in this study might be due to small sample size i.e. 18 in comparison to 132 and also due to winter season because survival times of enteric bacteria are longer at cooler, (but above freezing) temperatures but their multiplication rate is increased at summer temperatures (EC 2001b).
The mean load of total and faecal coliforms of 17 biowaste samples and 18 bioslurry samples were found to be reduced. There was significant correlation between the anaerobic digestion of biogas plant and the load of total coliforms $(\mathrm{P}<0.001)$ and faecal coliforms $(\mathrm{P}=0.002)$. Therefore, utilization of biowastes in biogas plant can be expected to significantly decrease the pathogens present in the biowastes. Bioslurries and biosolids are the end products of anaerobic digestion processs so the microbial quality of bioslurries can be compared with the USEPA standard for biosolids. In this study, among 18 bioslurry samples, 8 samples met the faecal coliforms load criteria of class A biosolids $\left(<3 \log _{10}\right.$ MPN/ gram dry solids ) while the rest 10 bioslurry samples had crossed this limit and met class B biosolid standard $\left(<6.3 \log _{10}\right.$ MPN/ gram dry solids) (USEPA, 1992). But, the unit MPN/ gram dry solids of USEPA standard are compared with $\mathrm{cfu} / \mathrm{mL}$ of this study. Class A biosolids can be used without restriction whereas agricultural use of class B bioslurries should be made by limiting the kind of crops as well as controlling the harvesting and grazing time. It is therefore necessary to establish some regulation for assessment of microbiological quality.

This study showed that higher reduction of pathogens and indicator organisms could be achieved through batch digestion of biogas plant which was found to be statistically significant. This is supported by Martens et al. (1998) who stated that in batch digestion a sufficient pathogen reduction can be stated, whereas in continuous type the retention time may not be long enough to exclude the passage of not inactivated pathogens. Similarly, Kearney et al. (1993) found that the greater reduction of viable counts of $E$. coli and Salmonella Typhimurium and other bacteria in batch digestion than in continuous digestion. Bagge (2005) also reported that pathogens reducing effects can be verified by batch digestion. The higher chance of competition occurring between pathogenic bacteria and indigenous bacteria for the nutrients in batch digestion might be an important factor of reducing pathogens and indicators.

In this study, a statistically significant correlation was found between the feeding materials and the load of total coliforms $(\mathrm{P}=0.004)$ and faecal coliforms $(\mathrm{P}<0.001)$. Of course, the higher load of coliforms in the human and animal waste is due to the higher number of faecal coliforms present in the human and animal intestines which are excreted along with the faecal 
materials. Similarly, the greater reductions of total and faecal coliforms were found in small sized biogas plants which were of batch type but it was statistically insignificant. Thus, it can be said that the greater reduction of coliforms found was due to batch digestion but not due to size of the plant.

Anaerobic digestion of biowastes in biogas plant can be considered as effective treatment method for the reduction of indicators and pathogens and the degree of sanitizing the biowaste depends on digestion type and nature of biowaste but not on the size of the biogas plant.

\section{Acknowledgement}

Authors would like to express their sincere thanks to National College, Kathmnadu for providing the laboratory facilities and Biogas Sector Partnership-Nepal (BSP-Nepal) for providing research grant.

\section{References}

Albihn, A. 2001. Recycling biowaste - Human and animal health problems. Acta Vet. Scand., Suppl. 95:69-75.

American Public Health Association (APHA), American Water Works Association (AWWA) and Water Pollution Control Federation (WPCF). 1998. Standard methods for the examination for water and wastewater. $\left(20^{\text {th }}\right.$ edition), (Eds. L.S. Clescerl, A.E. Greenberg and A.D. Eaton) Washington, D.C., USA.

Bagge, E., L. Sahlström and A. Albihn. 2005. The effect of hygienic treatment on the microbial flora of biowaste at biogas plants. Water Res._39(20):4879-86.

Benatti, C.T., C.R.G. Tavares, B.P.D. Filho and M.L.R. Moitinho. 2002. Operation of a slow rate anaerobic digester treating municipal secondary sludge. Electron. J. Biotechnol. 5(3): 216-227

Cheesbrough, M. 2000. District laboratory practice in tropical countries. Cambridge University Press, UK. Pp.1-266.

Cheluvappa, R., R. Shimmon, M. Dawson, S.N. Hilmer, and D.G.Le. Couteur. 2008. Reactions of Pseudomonas aeruginosa pyocyanin with reduced glutathione. Acta Biochimica polonica. 55 (3): 571-580.

Cole, D. J., V.R. Hill, F. J. Humenik, and M.D. Sobsey. 1999. Health, safety, and environmental concerns of farm animal waste. Occup. Med. 14:423-448.

Côté, C., D.I. Massé and S. Quessy. 2006. Reduction of indicator and pathogenic microorganisms by psychrophilic anaerobic digestion in swine slurries. Bioresource Technology. 97:686-691
EC. 2001a. Biological treatment of biowaste. Working document, 2nd Draft. DG ENV.A.2/LM/biowaste/2nd draft Brussels: European Commission.

EC. 2001b. Evaluation of sludge treatments for pathogen reduction. Final report for the European Commission directorate-general environment. Retrieved from http:/ leuropa.eu.int

Jenkins, S.R., C.W. Armstrong and M.M. Monti. 2007. Health effects of biosolids applied to land: Available scientic evidence. Virginia Department of Health. Retrieved from http://www.vdh.virginia.gov/epidemiology/DEE/ documents/Biosolids.pdf

Karki, A.B., J.N. Shrestha and S. Bajgain. 2005. Biogas as renewable source of energy in Nepal, theory and development. BSP-Nepal.

Kearney, T.E., M.J. Larkin and P.N. Levett. 1993. The effect of slurry storage and anaerobic digestion on survival of pathogenic bacteria. J. Appl. Bacteriol.74:86-93.

Larsen, H.E., B. Munch and J. Schlundt. 1994. Use of indicators for monitoring the reduction of pathogens in animal waste treated in biogas plants. Zentralbl Hyg Umweltmed 195(5-6):544-55.

Lepeuple, A.S., G. Gaval, M. Jovic and M.R. de Roubin. 2004. Literature review on levels of pathogens and their abatement in sludges, soil and treated biowaste. The Energy Research Centers of the Netherlands, WP3 Hygienic Parameters, Horizontal Project. Retrieved from www.ecn.nl/docs/society/horizontal/hor6 pathogens.pdf

Martens, W., A. Fink, W. Philipp, A. Weber, D. Winter and R. Böhm. 1998. Inactivation of viral and bacterial pathogens in large scale slurry treatment plant. In: RAMIRAN, $8^{\text {th }}$ International conference on management strategies for organic waste use in agriculture. pp.529539.

Onbasli, D. and B. Aslim. 2008. Determination of antimicrobial activity and production of some metabolites by Pseudomonas aeruginosa B1 and B2 in sugar beet molasses. African Journal of Biotechnology 7(24):4614-4619.

Parawira, W. 2004. Anaerobic treatment of agricultural residues and wastewater: Application of high-rate reactors. Ph.D. dissertation. Department of Biotechnology, Lund University, Sweden.

Ridley, D.S. and B. C. Hawgood. 1995. The value of formalether concentration of fecal cysts and ova. Journal of Clinical Pathology 9:14-16.

Sahlström, L. 2003. A review of survival of pathogenic bacteria in organic waste used in biogas plants. Bioresource Technology 87:161-166. 
Sahlström, L., E. Bagge, E. Emmoth, A. Holmqvist, M.L. Danielsson-Tham, A. Albihn. 2008. A laboratory study of survival of selected microorganisms after heat treatment of biowaste used in biogas plants. Bioresource Technology 99:7859-7865.

Smith, S.R., N.L. Lang, K.H. Cheung and K. Spanoudaki, 2005. Factors controlling pathogen destruction during anaerobic digestion of biowastes, Waste Management. 25(4):417-425.
Strauch, D. 1991. Survival of pathogenic microorganisms and parasites in excreta, manure and sewage sludge. Rev. Sci. Tech. Off. Int. Epiz.10 (3):813-846.

Stout, B. A. 1984. Energy use and management in agriculture. Breton Publishers, Massachusets.

YSD. 2005. Pathological test of bioslurry from latrine attached and non-attached biogas plants. Final report submitted to biogas sector partnership- Nepal (BSPNepal) by Yashoda Sustainable Development (YSD) 